\title{
Geologic Map of the Near Side of the Moon
}

\author{
By Don E. Wilhelms and John F. McCauley
}

Prepared on behalf of the

National Aeronautics and Space Administration

and in cooperation with the

USAF Aeronautical Chart and Information Center

Geologic Investigations Series Map I-703 


\section{GEOLOGIC MAP OF THE NEAR SIDE OF THE MOON \\ By \\ Don E. Wilhelms and John F. McCauley}

\section{RATIONALE, METHODS, AND FORMAT}

The chief purpose of the 1:5,000,000-scale map is to summarize the current state of lunar geologic knowledge as developed from the U.S. Geological Survey's systematic lunar mapping program, which began in 1960. Like terrestrial synoptic maps it provides a stratigraphic framework to be used for developing new theory and for determining the regional significance of surface exploration results. The geologic summary which accompanies the map gives the major genetic and historical conclusions which stem from the work. The map explanation provides the descriptive details that led to these conclusions. This pamphlet discusses the rationale, methods, and nomenclature of lunar stratigraphy, specifically for those interested in why and how the map was produced.

The work is based both on results of the telescopic mapping program and on data from the unmanned lunar exploration program, particularly the regional coverage of Lunar Orbiter IV ${ }^{\prime}$ The early telescopic studies established the geologic heterogeneity of the Moon and produced a workable nearside stratigraphy (Shoemaker and Hackman, 1962; McCauley, 1967b; Wilhelms, 1970b). Prior to the Lunar Orbiters, telescopic resolution limitations dictated emphasis on the grosser aspects of lunar geology: the structures and ejecta blankets associated with the multiringed basins, the major craters, and the stratigraphic relations between the generally younger maria and older terrae. The main products of the telescopic work were $361: 1,000,000$-scale geologic quadrangle maps (those marked " $T$ " in table 1) and a 1:5,000,000-scale preliminary map of the region $32^{\circ} \mathrm{N}$. to $32^{\circ} \mathrm{S}$. and $70^{\circ} \mathrm{E}$. to $70^{\circ} \mathrm{W}$. (Wilhelms, Trask, and Keith, 1965). Before the systematic program began, Hackman and Mason (1961) produced a set of three nearside maps at a scale of $1: 3,800,000$ from telescopic data; these maps emphasized the geology, physiography and ray- crater distribution.

'Useful collections of photographs from all Orbiter missions, accompanied by geologically oriented explanations, appear in Lowman (1969) and Kosofsky and El-Baz (1970).

TABLE I.-Authors, dates, data sources, and publication status of U.S. Geological survey 1:1,000,000-scale geologic maps (see index map on map sheet)

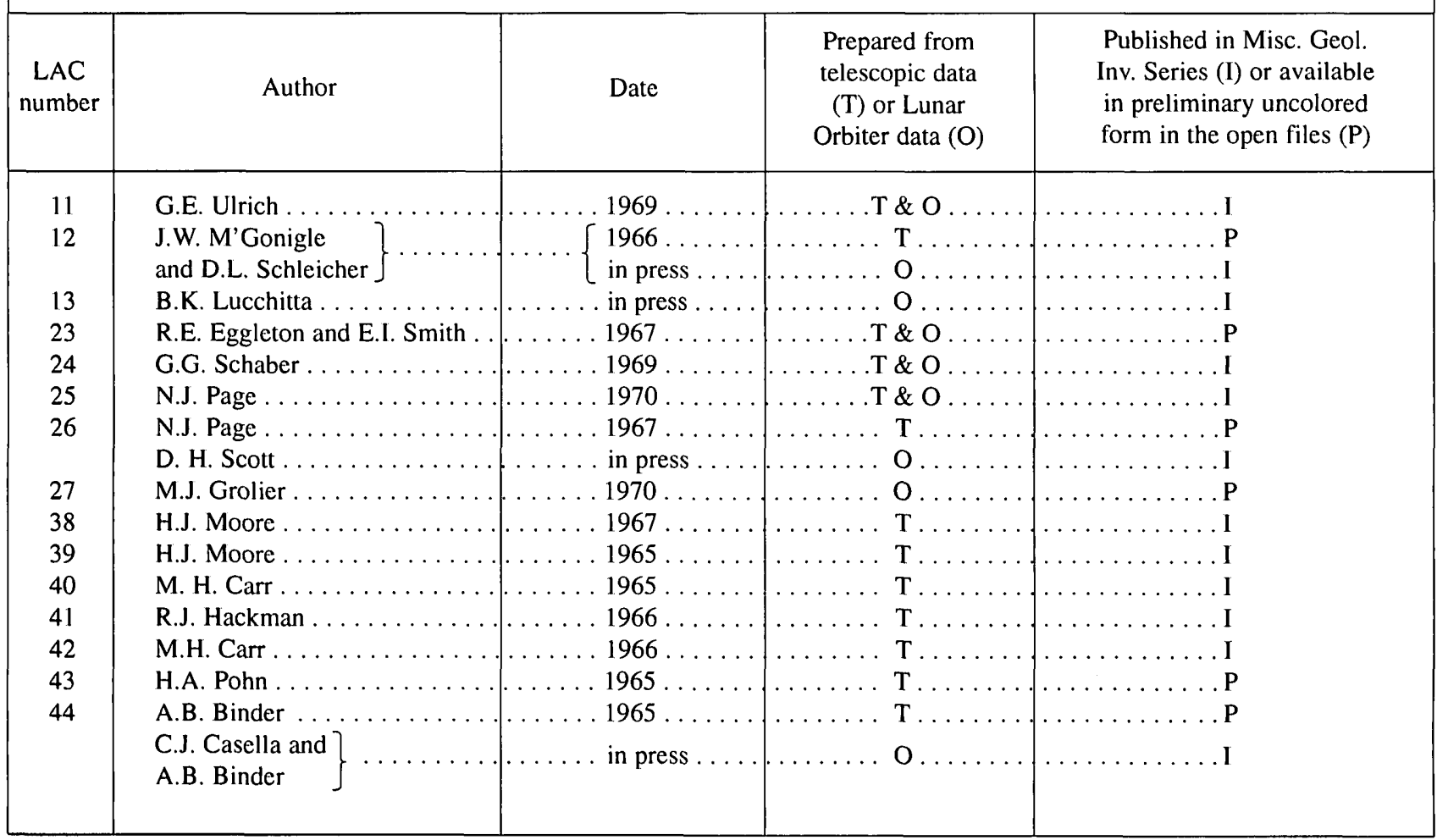




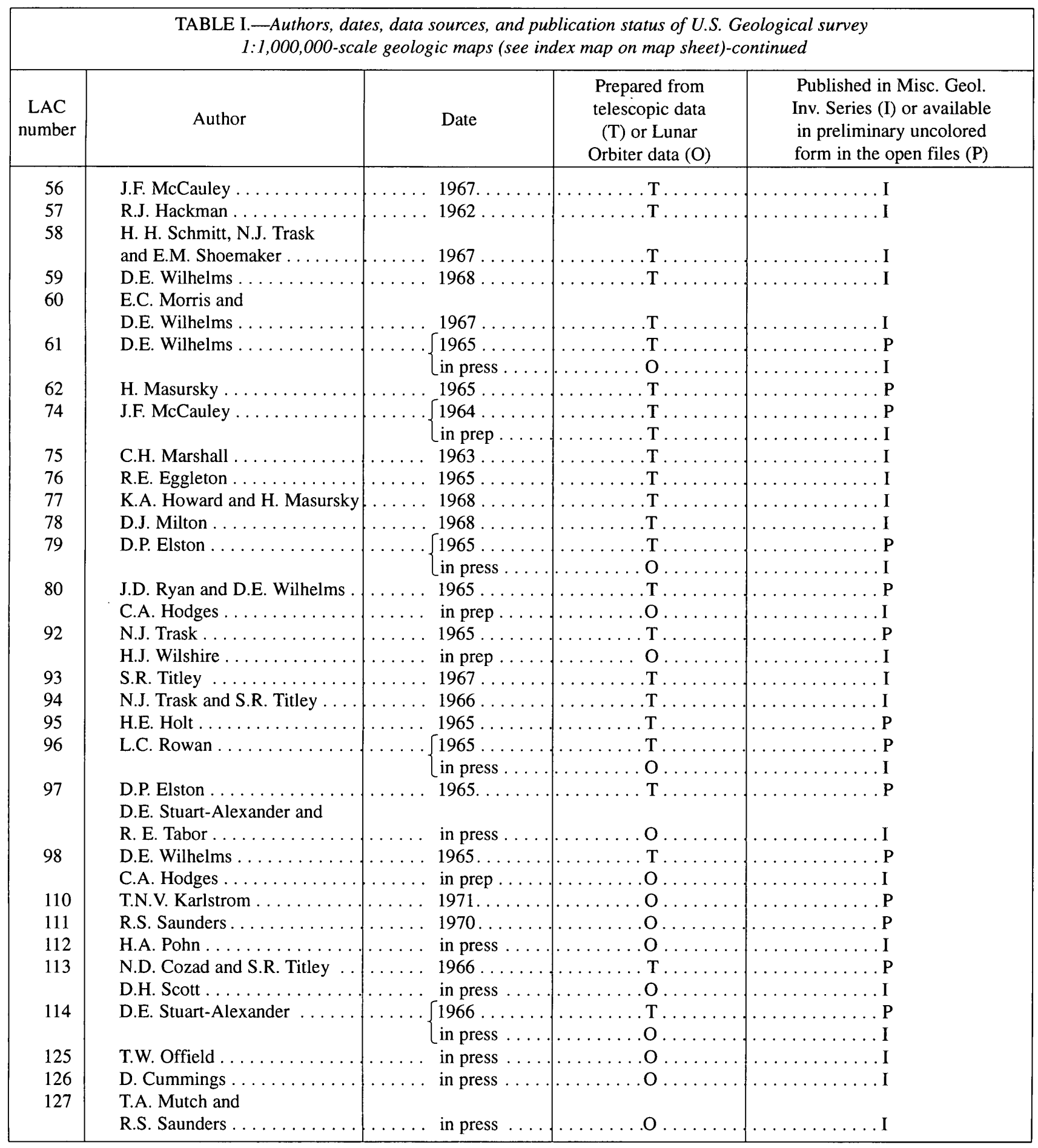

Lunar Orbiter mission IV, May 1967, provided lowsun photographs of most of the near side of the Moon at a resolution about 10 times better than that of telescopic photographs. 2 Approximately 108 usable photographs whose original readout scale is approximately 1:700,000 cover the area mapped. At Orbiter IV resolution-70 to $150 \mathrm{~m}$-the surface of the Moon exhibits a wide variety of land-surface forms, many of which,

${ }^{2}$ The skill of the Lunar Orbiter Project Office, Langley Research Center, NASA, and of The Boeing Company in planning and executing this highly productive spaceflight is gratefully acknowledged. especially in the terrae, are not seen or are difficult to describe and delineate on Earth-based photographs. The resolution and the equally important contiguous coverage attained by Orbiter IV permitted construction of more detailed and meaningful 1:1,000,000-scale maps, particularly of the terrae, and prompted the preparation of this more refined and areally expanded successor to the earlier 1:5,000,000 map. 
This pamphlet supplements several other explanations of the methods and rationale of lunar mapping. Shoemaker and Hackman (1962) summarized the stratigraphy used at the outset of the lunar mapping program. McCauley (1967b) summarized major pre-Orbiter results with emphasis on the rock-stratigraphic approach. Wilhelms (1970b) described in detail the rationale and theory of telescopic geologic mapping of the Moon and the evolution of lunar stratigraphic nomenclature. Trask (1970a) described the techniques for preparation of special large-scale maps $(1: 100,000$ and 1:25,000) prepared in support of the Apollo program and their relation to the 1:1,000,000-scale reconnaissance maps. Mutch (1970) reviewed the broad range of lunar geological investigations of the last decade and stressed the importance of the historical approach derived from longstanding terrestrial geologic practice. In addition, some discussion of methods and nomenclature is given in the explanatory material accompanying most published maps. Lunar students not acquainted with the geologic approach are referred to the excellent collection of articles and annotated references on the philosophy and methodology of geology in the book "The Fabric of Geology" (Albritton, 1963).

Because a permanent and dynamic atmosphere and hydrosphere are absent, the Moon at certain scales is actually more amenable to remote geologic analysis based principally on photographic data than is most of the Earth. On Earth most 100-m scale landforms, except in youthful volcanic provinces, are secondary and produced by the sculpturing effects of water, ice, or wind; thus these landforms are not readily relatable to the parent materials from which they form. On the Moon the main surfacesculpting forces seem to be meteorite bombardment and the downslope movement of fragmental debris into local depressions. At resolutions of $30 \mathrm{~m}$ and better the effects of this type of degradation tend to dominate the scene and almost all surfaces are covered with its product, a particulate regolith, the depth of which apparently depends primarily on the relative age of the surface. At the lower resolution of Orbiter IV, however, the effects of this surficial layer are not as significant, and many primary features such as crater deposits, circumbasin blankets, and positive constructional forms are evident. Moreover, subdued subtly expressed forms can be recognized and often identified confidently as older equivalents of more clearly expressed features that occur elsewhere on the Moon. A comparison of the detailed physiographic properties of craters similar in size such as Tycho (very fresh), Copernicus (somewhat "worn"), and Eratosthenes (fine details obscured) serves to illustrate this point. Thus uniformitarianism in a general sense is as applicable to the Moon as to the Earth; the most youthful and best preserved lunar surface features are the key to recognition of older, degraded, and more subtly expressed forms. The work of Shoemaker (1962, p. 323-347) on the ray crater Copernicus and that of McCauley (1967b, p. 439-446) on the Orientale basin are examples of the utility of studies of young features for the insights they provide about less well expressed landforms.

This map, like all geologic maps of the Moon, of the Earth, and those that might be made of the other terrestrial planets (Carr, ed., 1970), is a combination of observations and interpretations whose accuracy and degree of certainty depend on available data and current cumulative geologic knowledge. Geological analysis helps primarily to reduce the apparent disorder of any complex surface by dividing it into units, each with a limited set of distinctive properties. This is accomplished by delineating areas of relatively uniform textural and albedo characteristics. Judgment as to the relative importance of these observable properties and objective delineation of units are equally critical elements; the units must be both stratigraphically meaningful and sufficiently objective to be recognized by other workers viewing the same photographic data. The goal is to portray units that are not just similar-appearing surfaces or collections of similar topographic forms but, rather, three-dimensional bodies of finite horizontal and vertical extent which are in effect the building blocks of the visible part of the crust. In most instances the units can be treated conceptually as rockstratigraphic units (Am. Comm. on Strat. Nomenclature, 1961, Art. 4). The origin of these units-whether by impact, volcanism, or some other process-need not be known initially, although genesis is of course an ultimate objective. Lithologic properties or ranges of possible lithologies can be ascribed to many units on the basis of terrestrial field and experimental studies, as well as data from Surveyor and Apollo. Every effort is made, however, to eliminate genetic bias, and interpretations are separated from descriptions of the physical characteristics of each unit.

Each material unit is placed in order of age relative to its neighboring units on the basis of superposition and transaction relations. The application of these easily understood, long-established, and almost self-evident geometric relations is the heart of geologic mapping and introduces the dimension of time which allows the reconstruction of the Moon's geologic history. As on Earth, the uppermost rocks in a sequence are younger than those on which they lie; rocks cut by faults are older than the faults. Temporal relations are commonly revealed in the areal pattern of the units and their surface contact relations; a younger unit overlaps or embays an older unit; the contact of a younger unit cuts across the contact between two older units. Physiographic state of preservation and density of superposed craters are two additional means of estimating relative age, possible on the Moon only because of the lack of differing climatic zones. The 
inability of some workers to apply effectively these conceptually simple but rigorous tools has led to the misinterpretation of many fundamental relations, such as that between the maria and the older basins which they fill.

Once each local unit is dated relative to its neighbors, all occurrences with the same properties and apparent relative age or range of ages are included together in a map unit. In the case of craters, where two occurrences of a map unit of slightly different age are in contact. the younger crater is shown overlapping the older. Each map unit is assigned to one or more Moon-wide groupings of rocks, called timestratigraphic units, in order to relate it to the total lunar stratigraphic record. The time-stratigraphic classification first defined in the Mare Imbrium region by Shoemaker and Hackman (1962), with modifications by McCauley (1967b) and Wilhelms (1970b), is used here. There are three formal systems, the Copernican (youngest), Eratosthenian, and Imbrian, and one informal system, the preImbrian. A period of lunar geologic time of presently unknown duration corresponds to each of these. Following are the units of the Mare Imbrium region which comprise these systems ${ }^{3}$

\begin{tabular}{cl} 
SYSTEM (PERIOD) & \multicolumn{2}{c}{ UNITS } \\
Copernican & $\begin{array}{l}\text { Deposits of Copernicus and } \\
\text { other fresh-appearing rayed } \\
\text { craters }\end{array}$
\end{tabular}

Deposits of Eratosthenes and Eratosthenes similar slightly subdued craters whose rays are no longer visible or are very faint at high sun illuminations

Dark mare materials in the Imbrium basin and Oceanus Procellarum

Deposits of Archimedes and other mare-flooded craters superposed on circum-Imbrium deposits and structures

Circum-Imbrium deposits and structures

Deposits of Julius Caesar and other similar degraded craters covered by Imbrium basin deposits and cut by its structures

Extensive and synchronous stratigraphic datum planes are used for regional correlation where possible. Recognition of the distinctive deposits and structures around the Imbrium, Orientale, and Nectaris basins per-

${ }^{2}$ The stated age of a geologic unit is the age of its emplacement, not the age of crystallization of its component rocks, which in the case of impact units may substantially predate the emplacement. mits determination of events that precede, are synchronous with, or postdate these large basins. Additional widespread synchronous deposits around the rims of large craters such as Copernicus and Eratosthenes and approximately synchronous deposits such as the Imbrian mare material also are valuable stratigraphic datum planes. The determination of relative ages of craters in the terrae and in areas where these datum planes are not well developed is a special problem. Such craters are dated by morphologic methods described by Pohn and Offield (1970; Offield, 1971) which permit time-stratigraphic assignment in regions where previously only broad age ranges could be established. Although less desirable than more direct stratigraphic methods (using regional blankets as marker horizons or superposition and intersection relations), the dating of craters by their physiographic appearance works well in practice if age categories are not too finely drawn. The results are consistent with established stratigraphic relations where they can be tested. For example, no severely degraded craters of the type assigned to the preImbrian can be identified on either the Imbrium or the Orientale circumbasin units.

Each map unit is given a distinctive name, letter symbol, and color. Most names are abbreviated descriptions, but formal names are applied here to four circumbasin units of unwieldy description that are of special stratigraphic significance. The symbol for a unit consists of an abbreviation of the age (capital letter) and of the name (lowercase). Considerable age variation is recognized among individual occurrences of many nap units, and for these units only the predominant age of the collective occurrences is shown. Units that may belong with equal likelihood to either of two systems or any of three are given two capital letters representing the possible range (youngest first). The ages of individual occurrences of a unit relative to other units sometimes can be read from local super-position relations. Boxes for the map units are arranged vertically in the explanation with the youngest at the top and the oldest at the bottom and laterally by class or category of materials. The major classes are: dark materials (mostly of the flat maria); circumbasin materials; materials of terra plains, plateaus, and domes (the non-basin terra); and crater materials; these classes are further subdivided into categories mainly on the basis of topographic properties.

Beneath the array of color-keyed boxes are general descriptions and interpretations for each major class of materials and the essential descriptive data for each map unit. The first item in each unit description is type area, which is the lunar equivalent to the type section of terrestrial practice. The type area is the locality where the unit is most distinctive; to be correlated with this occurrence, other occurrences must possess most of the stated characteristics. The second item lists units of other map series, mostly of the $1: 1,000,000$-scale, which have been includ- 
ed in each unit on the present map, except where the present treatment is substantially novel. The third and fourth items describe and interpret the unit; as on previous U.S. Geological Survey lunar geologic maps, the salient topographic and albedo characteristics, distribution, and age relations of the units are given in a separate paragraph from genetic interpretations. Colors are assigned with the intent to associate materials of like type and age and separate unlike ones. The map and explanation, therefore, combine to give a picture of the distribution in time and space of the various kinds of materials which compose the visible parts of the lunar surface.

Most features $10 \mathrm{~km}$ and larger are geologically classified on this map. Small clustered features shown on the $1: 1,000,000$-scale maps are frequently combined into single patches or omitted if they do not contribute to the portrayal of regional relations. In many places contact relations have been generalized in order to emphasize age relations. Because of foreshortening in the limb regions on the orthographic base, the areas beyond longitudes and latitudes of $50^{\circ}$ are more generalized than the central parts of the map. Many units are defined somewhat differently than on previous maps, and other units have been combined in order to keep the number of units to a minimum and to standardize the presentation. In addition, the necessity of correlating units by the same criteria over the whole nearside has led to some differences from the previous maps in age assignments. Structures are omitted, except the concentric rings of the multi-ring basins and those coincident with unit contacts and implied by stratigraphic relations. The authors plotted the contacts exclusively from Orbiter IV photographs and thus did not strictly compile earlier work, although they have relied extensively on the results of the 1:1,000,000 series (table 1).

The type of analysis presented on the 1:5,000,000 lunar geologic map, and indeed all remote planetary mapping, can be considered as geological taxonomy. In addition to serving as a framework for interpreting surface exploration results, the effort to classify units into type and age by photogeology narrows the range of possible origins for many features. An absolute time scale cannot be derived directly from the relative stratigraphy shown, and attempts to establish absolute ages based on crater counts and meteorite and cometary flux data (Shoemaker and others, 1962; Gault, 1970) are independent of this work. Preliminary radiometric dating of the samples returned from the Apollo program has produced the first reliable correlation between the terrestrial and lunar time scales (see geologic summary). Future Apollo results will permit more detailed correlation and should render a new significance to the relative stratigraphy shown on the map.

\section{REFERENCES CITED IN PAMPHLET AND ON MAP SHEET}

Albritton, C.C., Jr., 1963, Fabric of geology: Reading, Mass., Addison-Wesley, $372 \mathrm{p}$.

American Commission on Stratigraphic Nomenclature, 1961, Code of stratigraphic nomenclature: Am. Assoc. Petroleum Geologists Bull., v. 45, no. 5, p. 645-665; correction; no. 6, p. 1001.

Baldwin, R.B., 1949, The face of the Moon: Chicago, Univ. Chicago Press, 239 p.

1963, The measure of the Moon: Chicago, Univ. Chicago Press, $488 \mathrm{p}$.

Carr, M.H., 1965, Geologic map and section of the Timocharis region of the Moon: U.S. Geol. Survey Misc. Geol. Inv. Map 1-462.

1966, Geologic map of the Mare Serenitatis region of the Moon: U.S. Geol. Survey Misc. Geol. Inv. Map 1-489. 1970 , Geologic map of the Maskelyne DA region of the Moon: U.S. Geol. Survey Misc. Geol. Inv. Map 1-616.

Carr, M.H., ed.,1970, A strategy for the geologic exploration of the planets: U.S. Geol. Survey Circ. 640, 37 p.

Cummings, David, 1971, Geologic map of the Wichmann CA region of the Moon: U.S. Geol. Survey Misc. Geol. Inv. Map 1-624.

Dietz, R.S., 1946, The meteoritic impact origin of the Moon's surface features: Jour. Geology, v. 54, no. 6, p. 359-375.

Dodd, R.T., Jr., Salisbury, J.W., and Smalley, V.G., 1963, Crater frequency and the interpretation of lunar history: Icarus, $v$. 2, no. 5-6, p. 466-480.

Eggleton, R.E., 1964, Preliminary geology of the Riphaeus quadrangle of the Moon and definition of the Fra Mauro Formation, in Astrogeologic Studies Ann. Prog. Rept., August 1962-July 1963, pt. A: U.S. Geol. Survey open-file report, p. 46-63.

1965, Geologic map of the Riphaeus Mountains region of the Moon: U.S. Geol. Survey Misc. Geol. Inv. Map 1-458.

Fielder, Gilbert, and Fielder, J., 1968, Lava flows in Mare Imbrium: Seattle, Wash., Boeing Sci. Research Labs. Doe. Dl-82-0749, 43 P.

Gault, D.E., 1970, Saturation and equilibrium conditions for impact cratering on the lunar surface-Criteria and implications: Radio Science, v. 6, no. 2, p. 273-291.

Gilbert, G.K., 1893, The Moon's face-a study of the origin of its features: Philos. Soc. Washington Bull., v. 12, p. 241292. 5

Green, Jack, 1962, The geosciences applied to lunar exploration, in Kopal, Zdenek, and Mikhailov, Z.K., eds., The Moon-Internat. Astron. Union Symposium 14, Leningrad 1960, Proc.: New York, Academic Press, p. 169-257.

Hackman, R.J., 1961, Photointerpretation of the lunar surface: Photogramm. Eng., v. 27, no. 3, p. 377-386 (with fold-in map supplement). 1966, Geologic map of the Montes Apenninus region of the Moon: U.S. Geol. Survey Misc. Geol. Inv. Map 1-463.

Hackman, R.J., and Mason, A.C., 1961, Engineer special study of the surface of the Moon: U.S. Geol. Survey Misc. Geol. Inv. Map 1-351 (3 maps and expl.). 
Hartmann, W.K., and Kuiper, G.P., 1962, Concentric structures surrounding lunar basins: Arizona Univ. Lunar and Planetary Lab. Commun., v. 1, no. 12, p. 51-66.

Kosofsky, L.J., and El-Baz, Farouk, 1970, The Moon as viewed by Lunar Orbiter: U.S. Natl. Aeronautics and Space Adm. Spec. Flub. SP-200, 152 p.

Kuiper, G.P., ed., 1950, Photographic lunar atlas: Chicago, Univ. Chicago Press.

1965, Interpretation of Ranger VII records, in Ranger VII, Pt. 2- Experimenters' analyses and interpretations: California Inst. Technology, Jet Propulsion Lab. Tech. Rept. 32-700, p. 9-73; reprinted, 1966, with slight revisions: Arizona Univ. Lunar and Planetary Lab. Commun., v. 4 , pt. 1 , no. 58 , p. $1-70$.

Kuiper, G.P., Whitaker, E.A., Strom, R.G., Fountain, J.W., and Larson, S.M., 1967, Consolidated lunar atlas, Supp. nos. 3 and 4 to the USAF photographic lunar atlas: Arizona Univ. Lunar and Planetary Lab. Contr., no. 4, 24, p., 226 photos.

Lipskiy, Yu. N., 1965, Zond-3 photographs of the Moon's far side: Sky and Telescope, v. 30, no. 6, p. 338-341.

Lowman, P.D., Jr., 1969, Lunar panorama-A photographic guide to the geology of the Moon: Zurich, Reinhold A. Muller, $101 \mathrm{p}$.

Lunar Sample Analysis Planning Team, 1970, Summary of Apollo 11 lunar science conference: Science, v. 167, no. 3918 , p. $449-451$.

Lunar Sample Preliminary Examination Team, 1970, Preliminary examination of lunar samples from Apollo 12: Science, v. 167 , no. 3923 , p. $1325-1339$.

McCauley, J. F., 1967a, Geologic map of the Hevelius region of the Moon: U.S. Geol. Survey Misc. Geol. Inv. Map 1491.

1967b, The nature of the lunar surface as determined by systematic geologic mapping, in Runcorn, S.K., ed., Mantles of the Earth and terrestrial planets: New York, Interscience p. 431-460.

1968, Geologic results from the lunar precursor probes: AIAA Jour., v. 6, no. 10, p. 1991-1996.

McCord, T.B., 1969, Color differences on the lunar surface: Jour. Geophys. Research, v. 74, no. 12, p. 3131-3142.

Marshall, C.H., 1961, Thickness of the Procellarian System, Letronne region of the Moon, in Geological Survey research 1961: U.S. Geol. Survey Prof. Paper 424-D, p. D208-D211.

Mason, A.C., and Hackman, R.J., 1962, Photogeologic study of the Moon, in Kopal, Zdenek, and Mikhailov, Z.K., eds., The Moon-Internat. Astron. Union Symposium 14, Leningrad 1960, Proc.: New York, Academic Press, p. 301-315.

Milton, D.J., 1968, Geologic map of the Theophilus quadrangle of the Moon: U.S. Geol. Survey Misc. Geol. Inv. Map 1546.

Moore, H.J., 1965, Geologic map of the Aristarchus region of the Moon: U.S. Geol. Survey Misc. Inv. Map 1-465. 1967, Geologic map of the Seleucus quadrangle of the Moon: U.S. Geol. Survey Misc. Geol. Inv. Map 1-527.

Morris, E.C., and Wilhelms, D.E., 1967, Geologic map of the Julius Caesar quadrangle of the Moon: U.S. Geol. Survey Misc. Geol. Inv. Map 1-510.
Mutch, T.A., 1970, Geology of the Moon-A stratigraphic view: Princeton, N.J., Princeton Univ. Press, 324 p.

Offield, T.W., 197 1, Geologic map of the Schiller quadrangle of the Moon: U.S. Geol. Survey Misc. Geol,. Inv. Map 1691 [in press].

1972, Geologic map of the Flamsteed K region of the Moon: U.S. Geol. Survey Misc. Geol. Inv. Map 1-626 [in press].

Offield, T.W., and Pohn, H.A., 1970, Lunar crater morphology and relative age determination of lunar geologic units-Part 2. Application, in Geological Survey Research 1970: U.S. Geol. Survey Prof. Paper 700-C, p. C163-C169.

Oriti, R.A., and Green, Jack, 1967, Alternate interpretations of the Orientale basin: The impact origin of the Orientale basin, by R.A. Oriti and The volcanic origin of the Orientale basin, by Jack Green: Griffith Observer, v. 31, no. 8, p. $118-124$.

Page, N.J, 1970, Geologic map of the Cassini quadrangle of the Moon: U.S. Geol. Survey Misc. Geol. Inv. Map 1-666.

Pohn, H.A., and Offield,.T.W., 1970, Lunar crater morphology and relative age determination of lunar geologic units-Part 1. Classification, in Geological Survey research 1970: U.S. Geol. Sur- Prof. Paper 700-C, p. C153-C162.

Pohn, H.A., and Wildey, R.L., 1970, A photoelectric-photographic study of the normal albedo of the Moon: U.S. Geol. Survey Prof. Paper 599-E, 20 p.

Rowan, L.C., 1971, Geologic map of the Oppolzer A region of the Moon: U.S. Geol. Survey Misc. Geol. Inv. Map 1-620.

Schaber, G.G., 1969, Geologic map of the Sinus Iridum quadrangle of the Moon: U.S. Geol. Survey Misc. Geol. Inv. Map 1-602.

Schmitt, H.H., Trask, N.J., and Shoemaker, E.M., 1967, Geologic map of the Copernicus quadrangle of the Moon: U.S. Geol. Survey Misc. Geol. Inv. Map 1-515.

Scott, D.H., 1972, Geologic map of the Maurolycus quadrangle of the Moon: U.S. Geol. Survey Misc. Geol. Inv. Map 1695 [in press].

Sekiguchi, N., 1970, On the fissions of a solid body under influence of tidal force, with application to the problem of twin craters on the Moon: The Moon, v. 1, no. 4, p. 429439.

Shoemaker, E.M., 1962, Interpretation of lunar craters, in Kopal, Zdenek, ed., Physics and astronomy of the Moon: New York, Academic Press, p. 283-359.

1965, Preliminary analysis of the fine structure of the lunar surface in Mare Cognitum, in Ranger VII, Pt. 2Experimenters' analyses and interpretations: California Inst. Technology, Jet Propulsion Lab. Tech. Rept. 32-700, p. $75-134$.

Shoemaker, E.M., and Hackman, R.J., 1962, Stratigraphic basis for a lunar time scale, in Kopal, Zdenek, and Mikhailov, Z.K., eds., The Moon-Intern. Astronom. Union Symposium 14, Leningrad 1960. Proc.: New York, Academic Press, p. 289-300.

Shoemaker, E.M., Hackman, RI,41, and Eggleton, R. E., 1962, Interplanetary correlation of geologic time: Advances Astronaut. Sci., v. 8, p. 70-89.

Shorthill R. W., and Saari, J.M., 1969, Infrared observation, on the eclipsed Moon: Seattle, Wash., Boeing Sci. Research Labs. Dl-82-0778, 73 p. 
Smith, R.L., 1966, Terrestrial calderas,associated pyroclastic deposits, and possible lunar applications, in Hess, W.N., Menzel, D.H., and O'Keefe, J.A., eds., The nature of the lunar surface-1965 Internat. Astron. Union-U.S. Natl. Aeronautics and Space Adm. Symposium, Proc.: Baltimore, Md., Johns Hopkins Press, p. 241-257.

Spurr, J.E., 1944, Geology applied to selenology, v. I-The Imbrian plain region of the Moon: Lancaster, Pa., Sci. Press, $112 \mathrm{p}$.

Stuart-Alexander, D.E., 1971, Geologic map of the Rheita quadrangle of the Moon: U.S. Geol. Survey Misc. Geol. Inv. Map 1-694 [in press].

Titley, S.R., 1966, Seismic energy as an agent of morphologic modification on the Moon, in Astrogeologic Studies Ann. Prog. Rept., July 1965-July 1966, pt. A: U.S. Geol. Survey open- file report, p. 87-103.

Titley, S.R., 1967, Geologic map of the Mare Humorum region of the Moon: U.S. Geol. Survey Misc. Geol. Inv. Map 1495.

Trask, N.J., 1970a, Geologic maps of early Apollo landing sites: Supp. to U.S. Geol. Survey Misc. Geol. Inv. Maps 1-616-1-627.

1970b, Geologic map of the Apollo landing sites 3 and 3R: U.S. Geol. Survey Misc. Geol. Inv. Map 1-621.
Trask, N.J., and Titley, S.R., 1966. Geologic map of the Pitatus region of the Moon: U.S. Geol. Survey Misc. Geol. Inv. Map 1-485.

U.S. National Space Science Data Center, 1969, Lunar Orbiter photographic data, NSSDC 69-05: Greenbelt, Md., Goddard Space Flight Center, 37 p.; Supp., Special Lunar Orbiter information retrieval, $6 \mathrm{p}$.

West, Mareta, and Cannon, P.J., 1971, Geologic map of Apollo landing sites 4 and 4R: U.S. Geol. Survey Misc. Geol. Inv. Map 1-625.

Whitaker, E.A., 1966, The surface of the Moon, in Hess, W.N., Menzel, D.H., and O'Keefe, J.A., eds., The nature of the lunar surface-1965 Internat. Astron. Union-U.S. Nat. Aeronautics and Space Adm. Symposium, Proc.: Baltimore, Md., Johns Hopkins Press, p. 79-98.

Wilhelms, D.E., 1968, Geologic map of the Mare Vaporum quadrangle of the Moon: U.S. Geol. Survey Misc. Geol. Inv. Map 1-548.

Wilhelms, D.E., 1970a, Geologic map of Apollo landing site 1: U.S. Geol. Survey Misc. Geol. Inv. Map 1-617. $1970 \mathrm{~b}$, Summary of lunar stratigraphy- telescopic observations: U.S. Geol. Survey Prof. Paper 599- F, 47 p.

Wilhelms, D.E., Trask, N.J., and Keith, J.A., 1965, Preliminary geologic map of the equatorial belt of the Moon, in Astrogeologic Studies Ann. Prog. Rept. July 1964-July 1965, map supp.: U.S. Geol. Survey open-file report. 